\title{
CORPORATE SOCIAL RESPONSIBILITY: EVIDENCE FROM NEPALESE FINANCIAL SERVICE AND MANUFACTURING SECTORS
}

\author{
Bal Ram Chapagain, M. Phil.*
}

\begin{abstract}
This study, first, aims to trace the evolutionary path of definitions and perspectives on corporate social responsibility (CSR) particularly during the last fifty years or so and then examine the Nepalese financial service and manufacturing sector managers' strategic and moral views on CSR. Besides, it also seeks to measure the CSR performance of companies and examine the relationship between management views on CSR and actual CSR performance. The study finds that the trend on CSR thinking has moved from philanthropy to better stakeholder relations and competitive/strategic advantage of organizations and even nations. In Nepalese context, however, the moral view on CSR is stronger than strategic view on CSR. Likewise, the actual CSR efforts are not as greener as the views are. Responsibility towards government seems to be highest and the responsibility towards society is the lowest in both the sectors. Analysis also reveals that overall CSR performance of companies is much more correlated to the moral view on CSR than to the strategic view on CSR. In this context, the government, pressure groups and other stakeholders are also required to further encourage socially responsible corporate behaviour for more equitable and just society.
\end{abstract}

Key words: Corporate social responsibility, strategic view, moral view, CSR performance, financial service sector, manufacturing sector, Nepal

\section{INTRODUCTION}

The idea that business enterprises are responsible for attending to the needs of society is hardly new. Such an expectation is a western tradition with a documented history of at least 2,000 years (Holmes, 1976). In the context of Nepal, one can go back to the Licchavi period (400 - 750 A.D.) to find very clear examples of corporate social responsibility (CSR) in the form of philanthropic contribution such as constructing 'dharmasala' or a temple. The belief transcend from the religious belief of the potential punishment the person will have after his death (in 'Narka' - the hell), if he exploits too much and the reward he will enjoy after his death (in 'Swarga' - the heaven), if he makes some social or religious contribution (Legal, 2006).

* Mr. Chapagain is a Faculty Member of Management at Patan Multiple Campus, Faculty Member of White House-GSM and a freelance Management \& Training Consultant 
With the passage of time, the form of business, the domain of stakeholders and their expectations have undergone substantial change. So does the view on and the form of CSR. Now, motivations for engaging in CSR activities can broadly be divided into two categories: moral and strategic. The moral view postulates that behaving in a responsible way towards different segments of society is a moral duty of business regardless of tangible benefits to business. On the other hand, the strategic view postulates that the firm's efforts with respect to CSR are expected to have a positive influence on firm's financial results, at least, in the long term (Graafland and Ven, 2006). The purpose of this study is to trace the evolutionary path of CSR, degree of strategic and moral motivation or views of Nepalese managers for CSR, and to measure the relationship between their views and the actual CSR performance.

\section{LITERATURE REVIEW}

\section{Definitions of Corporate Social Responsibility}

Corporate social responsibility has been defined in a variety of ways. However, most of the literature refers it as corporate activities that are beyond economic motives and legal requirements, adding ethical and voluntary responsibilities of business towards society (Jones, 1980; Carroll, 1999; McWilliams and Siegel, 2001; Kok et al., 2001; Oppewal et al., 2006; Kim et al., 2010).

To Friedman: "There is one and only one social responsibility of business - to use its resources and engage in activities designed to increase its profits so long as it stays within the rules of the game, which is to say, engages in open and free competition without deception of fraud" (Friedman, 1970:126). Rejecting the idea of Milton Friedman, Drucker states that: "It is futile to argue, as Milton Friedman... that a business has only one responsibility: economic performance. Economic responsibility is the first responsibility of a business... Economic performance is the base without which a business cannot discharge any other responsibilities... But economic performance is not the only responsibility of a business" (Drucker, 1992:99, cited in Smith, 2008).

Carroll $(1979,1991)$ attempted to bring a more precise definition in view of what constitutes social responsibility of business by providing four levels of CSR: economic responsibilities, legal responsibilities, ethical responsibilities, and voluntary/ discretionary responsibilities. His multi-dimensional model of CSR has proved among the most widely referenced frameworks since it makes important principles, but researchers have yet empirically examined the dimensionality of CSR from an operational perspective.

Building on CSR models proposed by Carroll (1979, 1991), Kim et al. (2010) have attempted to propose a revised framework of CSR. In this revised framework, the pyramid depicts the three component of CSR, beginning with the grounding block of legal responsibility at the base. At the same time, business is expected to pursue economic performance in nature. Finally, businesses are expected to fulfill ethical responsibility 
to do what is right, just, and fair, and further to be a good corporate citizen to contribute to the society at large. They have argued that these three responsibilities should not be considered separate from one another. As the sum of each domain composes a whole pyramid, business is expected to fulfill all responsibilities simultaneously.

In brief, I attempt to define CSR at a broader meaning, building on the definitions that I elaborated above: "CSR is a business principle and/or practice which integrates legal, economic, ethical, social and environmental concerns and seeks to fulfill the interests of all stakeholders including the interest of business itself". In essence, CSR is not merely an obligation of business enterprises towards different stakeholders but, more importantly, an opportunity for economic success and sustainability.

\section{THEORETICAL PERSPECTIVES ON CSR}

Numerous theories have been brought to bear on the subject of CSR. Shareholder and stakeholder theories are the major ones that deal with CSR. Shareholder theory which is based on principal-agent argument of agency theory, limits the boundaries of CSR to the fiduciary duties of managers to stockholders (Gregg, 2001; Macey and O'Hara, 2003). On the other hand, stakeholder theory stresses the role of stakeholder relationships in the creation of organizational wealth (Freeman, 1984).

The main difference between shareholder theory and stakeholder theory is that while the former views the non-stockholders as a means to the end of profitability; the latter considers the interests of non-stockholders as ends (Hasnas, 1998).

Besides, some other important theories include stewardship theory, resource-based view of the firm, theory of the firm, institutional theory etc. To be noted, the typology for discussing perspectives on CSR varies from author to author. Lantos (2001) has discussed the perspectives on business' role in society under four headings as - the pure profit maximizing view, the constrained profit maximizing view, the socially aware view and the stakeholder model of CSR, and the community service view.

Table 1: Spectrum of Viewpoints on the Role of Business in Society

\begin{tabular}{|l|l|}
\hline Author & Position on business' role in society \\
\hline Albert Carr & $\begin{array}{l}\text { Pure profit-making view- economic CSR: business has lower standards of } \\
\text { ethics than society and no social responsibility other than obedience to the } \\
\text { law }\end{array}$ \\
\hline $\begin{array}{l}\text { Milton } \\
\text { Friedman }\end{array}$ & $\begin{array}{l}\text { Constrained profit-making view--economic CSR: business should maximize } \\
\text { shareholder wealth, obey the law, and be ethical }\end{array}$ \\
\hline $\begin{array}{l}\text { R. Edward } \\
\text { Freeman }\end{array}$ & $\begin{array}{l}\text { Socially aware view - ethical CSR: Business should be sensitive to potential } \\
\text { harms of its actions on various stakeholder groups }\end{array}$ \\
\hline $\begin{array}{l}\text { Archie } \\
\text { Carroll }\end{array}$ & $\begin{array}{l}\text { Community service view/corporate social performance perspective - } \\
\text { altruistic CSR: business must use its vast resources for social good }\end{array}$ \\
\hline
\end{tabular}


Likewise, Quazi and O'Brien (2000) have proposed four different views of CSR ranging from 'no provision for business to look beyond profit-making' to 'do well despite the costs involved'.

Table 2: Four Views of CSR (adapted from Quazi and O'Brien, 2000)

View Description

The classical view

The modern view

The philanthropic view
Reflects the orthodox neoclassical perspective discussed above, in which there is no provision for business to look beyond profit-making, and where CSR is seen to generate only costs but no benefits.

Represents a narrow view of social responsibility, coupled with acceptance of potential benefits to be associated with CSR as in the avoidance of regulation, building good customer and supplier relationships or networking. Here business continues to pursue profit maximization as a primary concern, while also trying to meet social demand and derive some benefits in the process.

Captures a perspective in which a business sees added value in serving a wider array of societal needs and expectations and perceiving net benefits to flow from socially responsible action. This is consistent with the stakeholder approach to CSR.

Depicts a broader view of social responsibility in which a business decides to undertake CSR actions even when the latter are generally perceived as a net cost. This stance may be enticed by a combination of altruistic/ethical motives to do well despite the costs involved.

Different perspectives or views have different focus and argument. Some have stressed the altruistic responsibilities while others are concerned to create sustainable competitive advantage. Some focus on the legal responsibilities but others on ethical responsibilities. However, the recent trend is mostly towards strategic. 
Table 3: Evolution of Theoretical Perspectives in CSR

\begin{tabular}{|c|c|c|c|c|c|}
\hline $1950 s$ & $1960 s$ & $1970 s$ & 1980s & 1990s & $2000 s$ \\
\hline \multirow{4}{*}{\multicolumn{2}{|c|}{$\begin{array}{l}\text { Moral duty } \\
\text { Responsibility oriented } \\
\text { Philanthropic }\end{array}$}} & \multicolumn{2}{|c|}{ Enlightened self-interest } & \multicolumn{2}{|c|}{ Competitive advantage } \\
\hline & & \multirow{2}{*}{\multicolumn{2}{|c|}{ Loose coupling with financial }} & \multirow{2}{*}{\multicolumn{2}{|c|}{$\begin{array}{l}\text { Tight coupling with financial } \\
\text { performance }\end{array}$}} \\
\hline & & & & & \\
\hline & & \multicolumn{2}{|c|}{ Stakeholder relations } & Busine & : Win-win \\
\hline
\end{tabular}

The dominant theme of CSR in 1950s and 1960s was an ethical and social responsibility which postulates that giving something back to society is the moral duty of business or businessman (Bowen, 1953, cited in Lee, 2008). But, in1970s and 1980s, CSR was thought as enlightened self-interest of business. The enlightened self-interest model, however, was more of a concept than a full-blown theoretical model (Lee, 2008). It mainly paid attention on better stakeholder relations. Now the institutionalized conceptions of CSR as reflected in management literature during the last fifty years have changed substantially. Corporate social responsibility is no longer conceived as a moral 'responsibility' of corporate managers for greater social good or executives' discretionary expenditure that could hamper a corporation's profitability, but as strategic resources to be used to improve the bottom line performance and competitiveness of the corporation (Mc Williams et al., 2006; Porter and Kramer, 2006) and even competitive advantage of nations (Swift and Zadek, 2002; Zadek, 2006).

\section{DATA AND METHODOLOGY}

\section{Nature and Sources of Data}

The primary data required for the study were collected through structured questionnaires. The sources of such data were the top, middle and lower level managers from financial service and manufacturing sector organizations of Nepal. To ensure full coverage of potential respondents, a current name list of all level managers were obtained from the human resource or the administration department of respective organizations.

\section{Sampling Framework}

The sample for this study consisted of different level managers of different companies from financial service and manufacturing sectors of Nepal. To decide the actual sample of the study, multistage random sampling technique was used. 


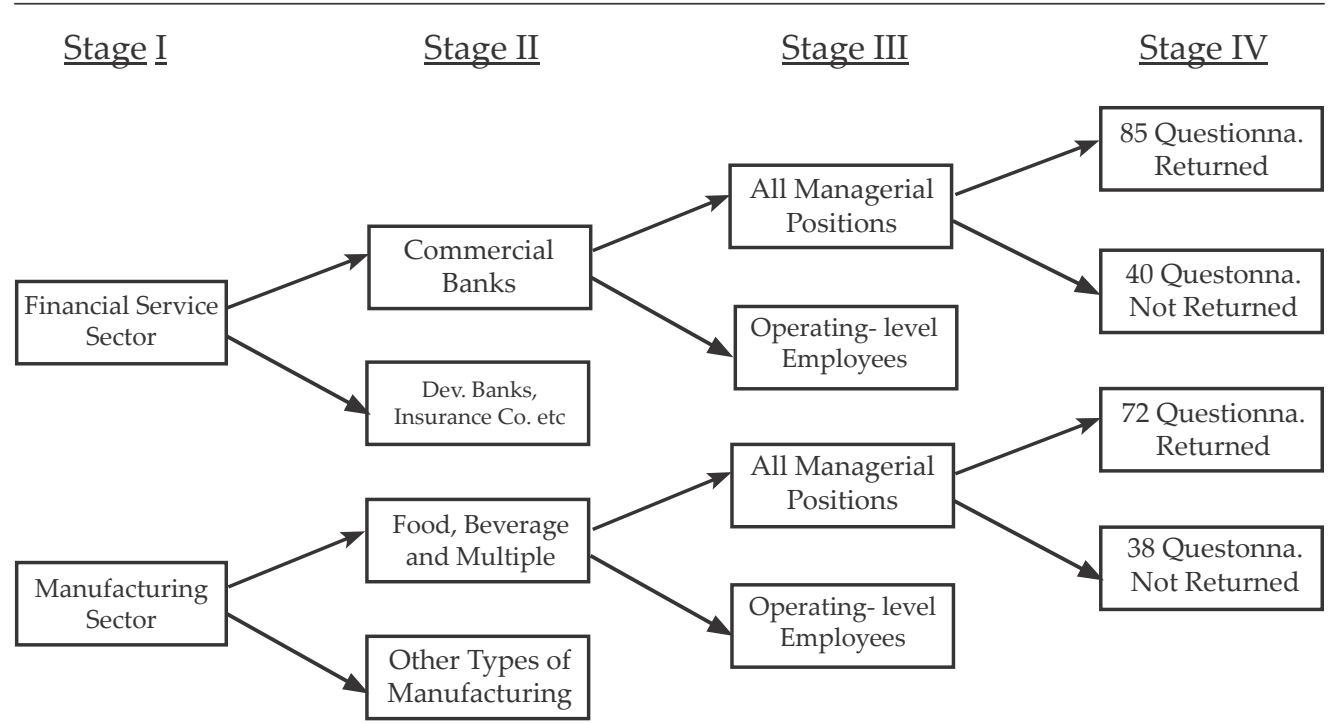

Figure 1: Sampling Framework

In total, 235 questionnaires were personally handed over to the financial service and manufacturing sector managers (financial service sector -125 , manufacturing sector - 110). Of which, 85 were received from financial service sector and 72 were received from manufacturing sector in useable forms. The high response rate (i.e., $68 \%$ from financial service sector and $65.45 \%$ from manufacturing sector, in aggregate) implies that the outcome can be regarded as representative of the complete sample of 235 respondents.

A crucial question is whether the answers of the respondents reflect social response bias or the actual situation. As the questionnaire was anonymous, respondents had no reason to present a more favourable picture than is in fact the case.

\section{Research Methodology}

This study partially followed the methodology adopted by Graafland and Ven (2006). In this study, two different corporate sectors (namely, financial service and manufacturing sectors of Nepal) were chosen to find answers to the research questions raised. In order to collect the primary data, survey instrument was organized into three sections: (i) General information about respondent; (ii) Strategic and moral views of managers on CSR; and (iii) Firm's CSR performance.

In order to analyze and interpret the data collected, descriptive statistics and correlation coefficients were used. Before performing any statistical tests, reliability of 
responses on scaled questions was tested by calculating Cronbach's Alpha. Cronbach's Coefficient Alpha was developed by Cronbach (1951) as a generalized measure of the internal consistency of a multi-item scale.

\section{RESULT AND DISCUSSION}

This study is mainly concerned with finding the degree to which Nepalese managers from financial service sector and manufacturing sector regard CSR as the moral duty of business and the degree to which they regard CSR as the strategic tool to enhance business competitiveness. It also seeks to measure CSR performance of companies and examine the relationship between managers' views on CSR and the actual CSR performance.

\section{Strategic and Moral Views of Managers on CSR}

Table 5.1.1 portrays the managers' response to the two different propositions on CSR. The first proposition measures the degree to which managers believe that firms efforts with respect to CSR will lead to the long term financial success of the organization (extrinsic or strategic motivation) and the second proposition or statement measures the degree to which managers regard CSR as moral duty of corporations (intrinsic or moral motivation). The respondents were actually asked to which extent they agreed or disagreed with the proposition on a five-point scale.

Table 4: Strategic and Moral Views of Managers on CSR

\begin{tabular}{|c|c|c|c|c|}
\hline \multirow[b]{2}{*}{$\begin{array}{l}\text { S. } \\
\text { N. }\end{array}$} & \multirow[b]{2}{*}{ Proposition } & \multicolumn{3}{|c|}{ Mean } \\
\hline & & $\begin{array}{l}\text { Financial } \\
\text { Service } \\
\text { Sector } \\
(\mathrm{N}=85)\end{array}$ & $\begin{array}{l}\text { Manufacturing } \\
\text { Sector }(\mathrm{N}=72)\end{array}$ & $\begin{array}{l}\text { Both Sectors } \\
\text { Combined } \\
(\mathrm{N}=157)\end{array}$ \\
\hline 1 & $\begin{array}{l}\text { Our firm's efforts with } \\
\text { respect to CSR are expected } \\
\text { to have a positive influence } \\
\text { on our financial results in the } \\
\text { long term (strategic view). }\end{array}$ & 4.07 & 3.35 & 3.74 \\
\hline 2 & $\begin{array}{l}\text { To behave in a responsible } \\
\text { way is a moral duty of } \\
\text { business towards society } \\
\text { (moral view). }\end{array}$ & 4.61 & 4.42 & 4.52 \\
\hline
\end{tabular}

Table 4 clearly shows that both the financial service and manufacturing sector managers have positive strategic and moral views towards CSR. It also indicates that financial service sector managers score more on strategic dimension (i.e., on the first 
proposition) than the manufacturing sector managers on the same. It implies that financial service sector managers are more optimistic about the financial payoff of CSR than manufacturing sector managers. It also indicates that both sector managers highly regard CSR as a moral duty of business than it as a tool for enhancing competitiveness or achieving financial success.

\section{CSR Performance in Nepalese Financial service and Manufacturing Sectors}

Figure 2 and Figure 3 present the level of CSR performance of the Nepalese financial service and manufacturing sectors, which is actually based on managers' responses on various aspects of CSR.

Observing Figure 2 it is noteworthy to mention here that manufacturing sector seems to be more involved in overall actual CSR efforts compared to financial service sector in Nepal but both the sectors have above-average involvement in most of the CSR efforts. However, both sectors have weak involvement in society aspect of CSR.

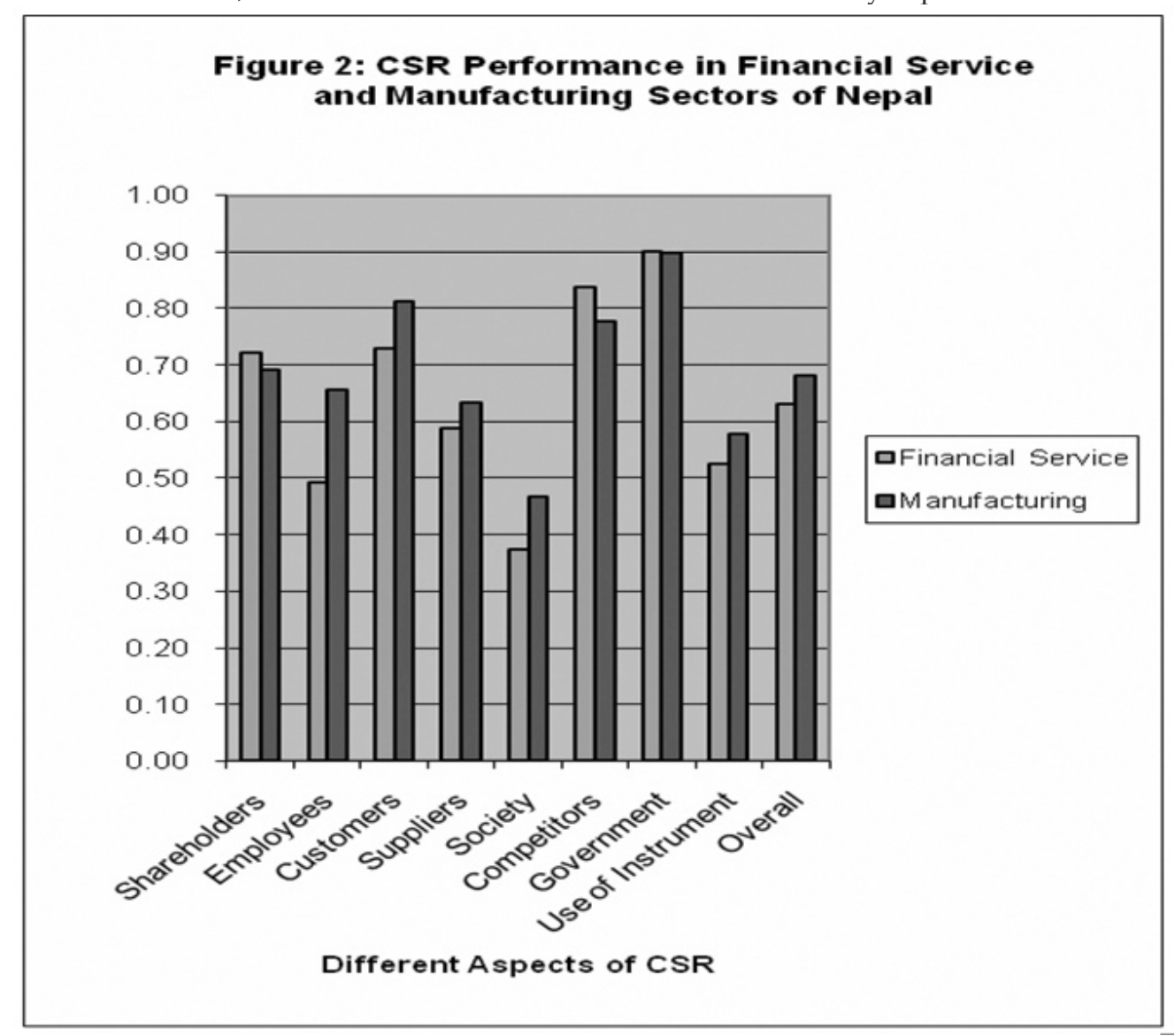


Figure 3: CSR Performance (both sectors combined)

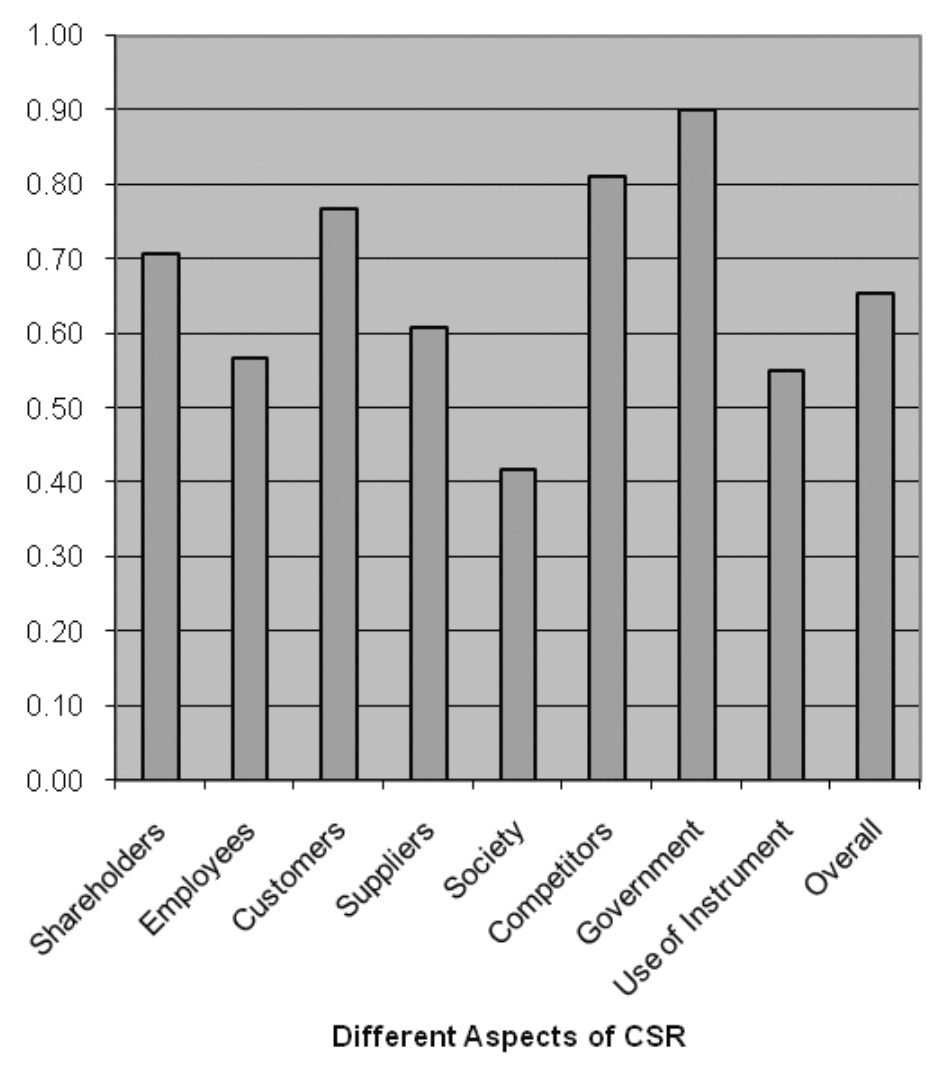

Likewise, Figure 3 reveals that there is a marked difference between the firms responsibility towards the government (highest) and towards the society (lowest). Similarly, Nepalese financial service and manufacturing sector firms have aboveaverage performance in almost all aspects of CSR (except society aspect).

\section{Relationship Between Managers' View on CSR and CSR Performance}

Figure 4 shows the relationship between different variables under study in the context of Nepalese financial service and manufacturing sectors.

Analysis reveals that overall CSR performance of companies is much more correlated to the moral view on CSR ( $r=0.34)$ than the strategic view on CSR $(r=0.15)$. 


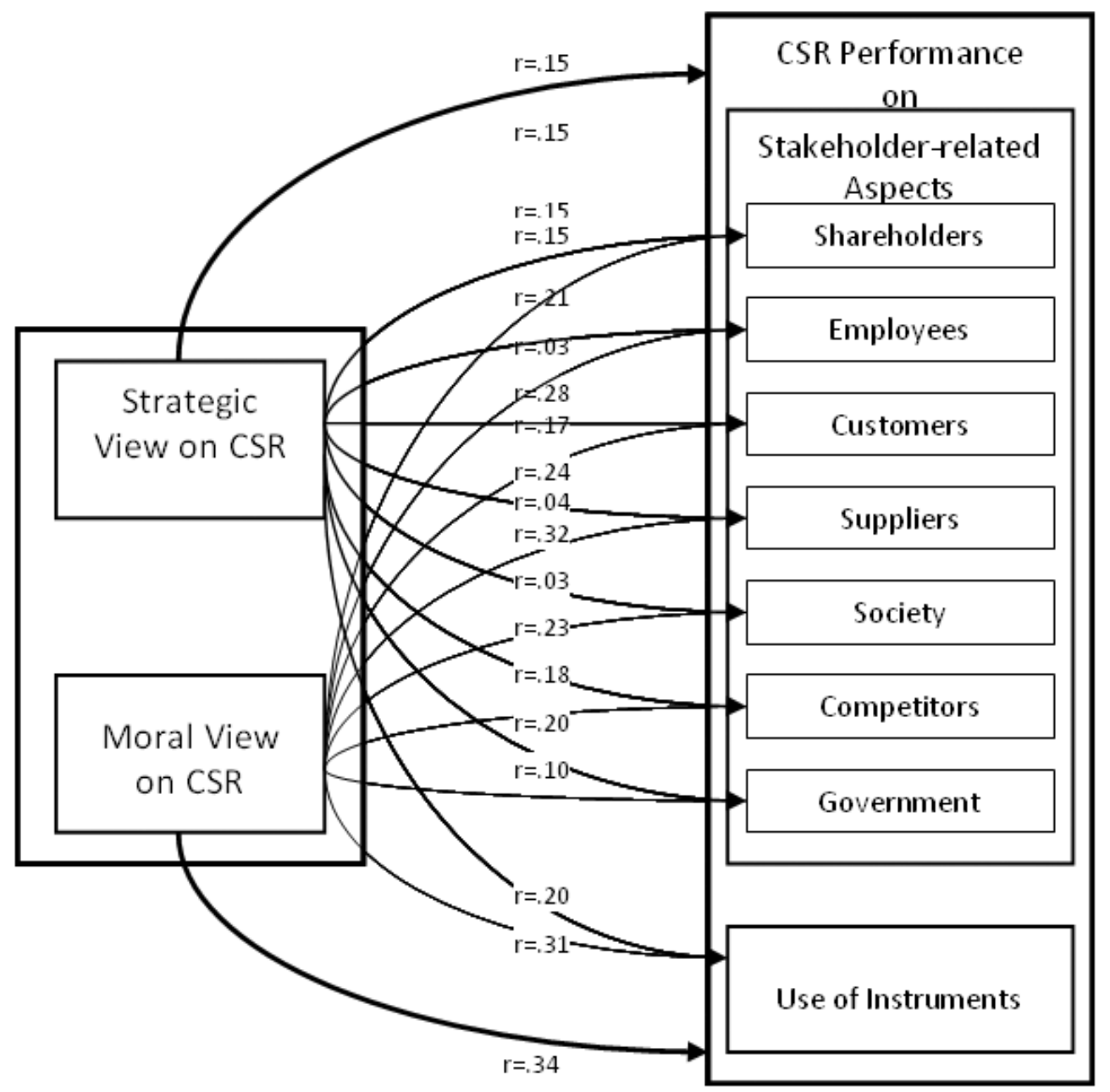

Figure 4: Relationship between Managers View on CSR and CSR Performance

The analysis also reveals that there is a weak positive relationship between the managers' strategic view on CSR and employees, suppliers and society related CSR performance. It indicates that Nepalese managers are still not convinced enough with the fact that contributing to the employee, suppliers and society needs pays of at least in the long term.

\section{CONCLUSION}

The growth of financial service and manufacturing sectors are the pivots of economic development of any country. The crucial issue is, however, to make the economic 
development of the country socially balanced and sustainable. To a great extent, whether the economic development is socially balanced can be predicted by managers' views on CSR and the actual CSR efforts (i.e., CSR performance) of companies.

The findings of this study show that a majority of respondents from both the sectors have positive strategic and moral views towards CSR. But, moral view is much stronger than the strategic view. It is generally argued that it is nice to talk or express views on CSR, but when it comes to reality, firms are reluctant. In Nepalese financial service and manufacturing sectors' context, though the actual CSR efforts are not as greener as the views are, there is a positive relationship.

This study reveals that though the managers of both sectors have positive views on strategic and moral dimensions of CSR, actual CSR performance of companies is not much encouraging, at least in all aspects of CSR. In this context, the government, pressure groups and other stakeholders are also required to encourage socially responsible corporate behaviour in order to sustain and increase their degree of positive views and actual practice on CSR. It may also be timely for the Nepalese government to consider introducing a social performance index and tax benefit or incentives for companies to benefit from such moves. Such moves would also enhance the level of participation and support by the corporate sector towards a more equitable and just society. Similarly, university systems should also incorporate and update CSR contents in their curricula in line with changing global scenario.

\section{References}

Carroll, A. (1979). A Three-dimensional Conceptual Model of Corporate Performance, Academy of Management Review, 4, 497-505.

(1991). The Pyramid of Corporate Social Responsibility: Toward the Moral Management of Organizational Stakeholders, Business Horizons, 39-48.

(1999). Corporate Social Responsibility: Evolution of a Definitional Construct, Business and Society Review, 38 (3), 268 - 295.

Cronbach, L. J. (1951). Coefficient Alpha and the Internal Structure of Tests, Psychometrika, 16, 407-422.

Friedman, M. (1970, September 13). A Friedman Doctrine: The Social Responsibility of Business Is to Increase Its Profits, The New York Times Magazine, 126.

Graafland, J. and Ven, V. B. D. (Summer 2006). Strategic and Moral Motivation for Corporate Social Responsibility, Journal of Corporate Citizenship, 111-123.

Gregg, S. (2001). Stakeholder Theory, Policy, 17 (2), 33-39.

Hasnas, J. (1998). The Normative Theories of Business Ethics: A Guide for the Perplexed, Business Ethics Quarterly, 8 (1), 19-42. 
Holmes, S. L. (1976). Executive Perceptions of Corporate Social Responsibility, Business Horizons, 34-40.

Jones, T.M. (1980). Corporate Social Responsibility Revisited, Redefined, California Management Review, $59-67$.

Kim, J. B., Kwak, G. and Koo, Y.R. (2010). A Note on Corporate Social Responsibility (CSR) in City Branding and Design, The Asian Journal on Quality, 11 (3), 251-265.

Kok, P., Wiele, T.V.D., McKenna, R. and Brown, A. (2001). A Corporate Social Responsibility: Audit within a Quality Management Framework, Journal of Business Ethics, 31 (4), 285 - 297.

Lantos, G. P. (2001). The Boundaries of Strategic Corporate Social Responsibility, Journal of Consumer Marketing, 18 (7), 595-630.

Lee, M.P. (2008). A Review of the Theories of Corporate Social Responsibility: Its Evolutionary Path and the Road Ahead, International Journal of Management Reviews, 10 (1), 53-73.

Legal, P. (2006, December 29). Corporate Social Responsibility: A Review of Practices in Nepal, In a seminar organized by Economic Forum Nepal (EFON), Kathmandu.

McWilliam, A. and Siegel, D. S. (2001). Corporate Social Responsibility: A Theory of the Firm Perspective, Academy of Management Review, 26 (1), 117-127. and Wright, P.M. (2006). Corporate Social Responsibility: Strategic Implications, Journal of Management Studies, 43, 1-18.

Macey, J. R. and O'Hara, M. (2003, April). The Corporate Governance of Banks, FRBNY Economic Policy Review, 91-107.

Oppewal, H., Alexander, A. and Sullivan, P. (2006). Consumer Perceptions of Corporate Social Responsibility in Town Shopping Centres and Their Influence on Shopping Evaluations, Journal of Retailing and Consumer Services, 13, 261-274.

Porter, M. E. and Kramer, M. R. (2006, December). Strategy and Society: The Link between Competitive Advantage and Corporate Social Responsibility, Harvard Business Review, 78-92.

Quazi, A. and O'Brien, D. (2000). An Empirical Test of a Cross-national Model of Corporate Social Responsibility, Journal of Business Ethics, 25, 33-51.

Smith, N.C. (2009). Bounded Goodness: Marketing Implications of Drucker on Corporate Social Responsibility, Journal of the Academy of Marketing Science, 37, 73-84.

Swift, T. and Zadek, S. (2002). Corporate Responsibility and the Competitive Advantage of Nations, The Copenhagen Centre and AccountAbility, Denmark.

Zadek, S. (2006). Corporate Responsibility and Competitiveness at the Macro Level - Responsible Competitiveness: Reshaping Global Markets through Responsible Business Practices, Corporate Governance, 6 (4), 334-348. Carroll, A. (1979). A Three-dimensional Conceptual Model of Corporate Performance, Academy of Management Review, 4, 497-505. 